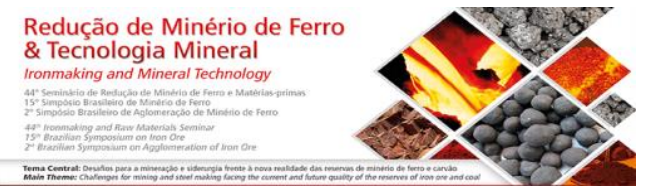

\title{
VERTICAL INTENSIVE MIXING FOR PROCESSING FINER IRON ORE IN SINTER PLANT*
}

\author{
Piezanowski Ludivine ${ }^{1}$ \\ Nouaille-Degorce Gilles ${ }^{2}$ \\ Hutsebaut Sven ${ }^{3}$ \\ Lumen Wouter ${ }^{4}$ \\ Van de Velde Frederik ${ }^{5}$ \\ Douce Jean-François ${ }^{6}$ \\ Van Loo Frédérique ${ }^{7}$
}

\begin{abstract}
With the aim to reduce the hot metal production cost, ArcelorMittal Gent decided to integrate more ores with finer particle size distribution in the raw material mix for the production of blast furnace sinter. As a consequence of such an increase of finer material in the sinter raw mix, the sinter machine productivity and the quality of the sinter are affected. In order to compensate this impact, modern granulation technology can be employed. Within this context, ArcelorMittal Gent has invested in a vertical intensive mixer. The equipment was placed before the existing drums, with a function of "mixer", whereas the drums are fully optimised for the nodulizing process. The paper presents the results of the industrial operation during the commissioning phase of the new equipment. Gradually increasing the proportion of fine material in the sinter raw mix has made it possible to compare the performances of the old system using drums for mixing and pelletizing with the new system using an intensive mixer combined with a nodulizing.
\end{abstract}

Keywords: Fine iron ore; Pellet feeds; Intensive mixer; Granulation; Sinter plant.

1 Project Engineer, Paul Wurth, Luxembourg, G-D of Luxembourg.

2 Head of technology for agglomeration department, Paul Wurth, Luxembourg, G-D of Luxembourg.

3 Support Manager Ironmaking, ArcelorMittal Gent, Gent, Belgium.

4 Support Manager Ironmaking, ArcelorMittal Gent, Gent, Belgium.

5 Head blast furnace and sinter plants, ArcelorMittal Gent, Gent, Belgium.

6 Research Engineer, ArcelorMittal Global R\&D, Maizières-les-Metz, France.

Senior Project Leader, CRM group, Liège, Belgium.

* Technical contribution to the $44^{\text {th }}$ Ironmaking and Raw Materials Seminar, $15^{\text {rd }}$ Brazilian Symposium on Iron Ore and $2^{\text {nd }}$ Brazilian Symposium on Agglomeration of Iron Ore, September $15^{\text {th }}$ to $18^{\text {th }}$, 2014, Belo Horizonte, MG, Brazil. 


\section{INTRODUCTION}

The evolution of the sinter ores, which become finer, on the market and the presence of more and more concentrate and pellet feed constrain steel makers to increase the ratio of ultra-fines material in their sintering process in order to remain competitive regarding the cost of hot metal production. But, when added as such in the sinter feed, this material has a detrimental impact on the sinter productivity and quality. One way to avoid such drawback is to define an appropriate granulation process.

After a long test campaign in laboratory, with the objective to compare different technologies regarding the introduction of ultra-fines material in the sinter line, ArcelorMittal decided to implement a vertical intensive mixer in Gent at SiFa\#2. The objective of the mixer was to process the whole raw material flow and to operate with a high ultra-fine ratio of total bedding.

The paper presents a comparison of the performance of an intensive mixer regarding the pelletizing rolling drums. The impact of intensive mixing on the intrinsic properties of the material and the hot sintering process will be detailed.

\section{MATERIAL AND METHODS}

\subsection{Lay-Out}

Up to 2012, the raw material preparation at SiFa\#2 in ArcelorMittal Gent was operated by the conventional system: one drum for the mixing of raw material followed by one nodulizing drum. After laboratory test campaigns based on the performance evaluation for the different granulation technologies regarding the increase of high level of ultra-fines material, ArcelorMittal decided to install a vertical intensive Mixer. The flow sheet of the installation is shown in figure 1.

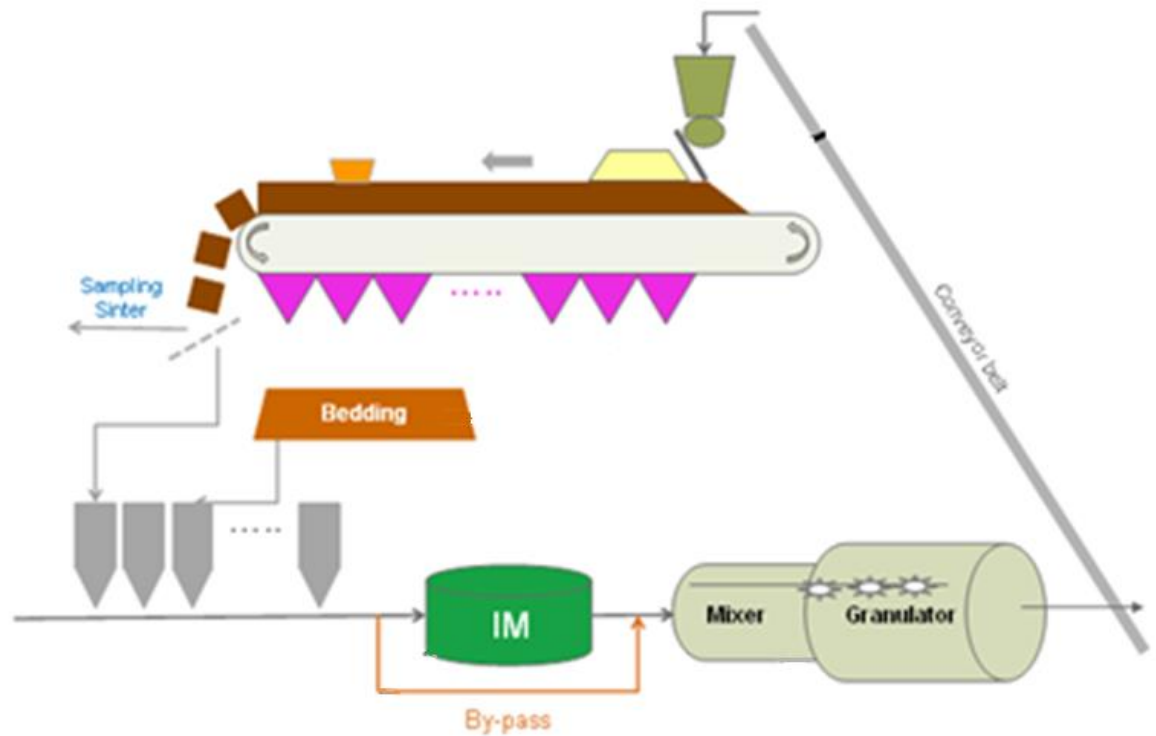

Figure 1. Implementation of the intensive mixer in ArcelorMittal Gent's flow sheet.

The intensive mixer was integrated in that precise function before the rolling drums, whereas the nodulizing process remained in the two conventional drums. The intensive mixer was designed to be able to process the entire flow of raw materials entering the sinter machine. They decided to keep the previous system composed of two drums (mixer and granulator) in order to be flexible and so as to compare the

* Technical contribution to the $44^{\text {th }}$ Ironmaking and Raw Materials Seminar, $15^{\text {rd }}$ Brazilian Symposium on Iron Ore and $2^{\text {nd }}$ Brazilian Symposium on Agglomeration of Iron Ore, September $15^{\text {th }}$ to $18^{\text {th }}$, 2014, Belo Horizonte, MG, Brazil. 
performance of the different tools. A by-bass chute for the intensive mixer was foreseen in the layout, to avoid stopping the sintering line process in case of maintenance or troubleshooting. Such a layout is presented in figure 2.

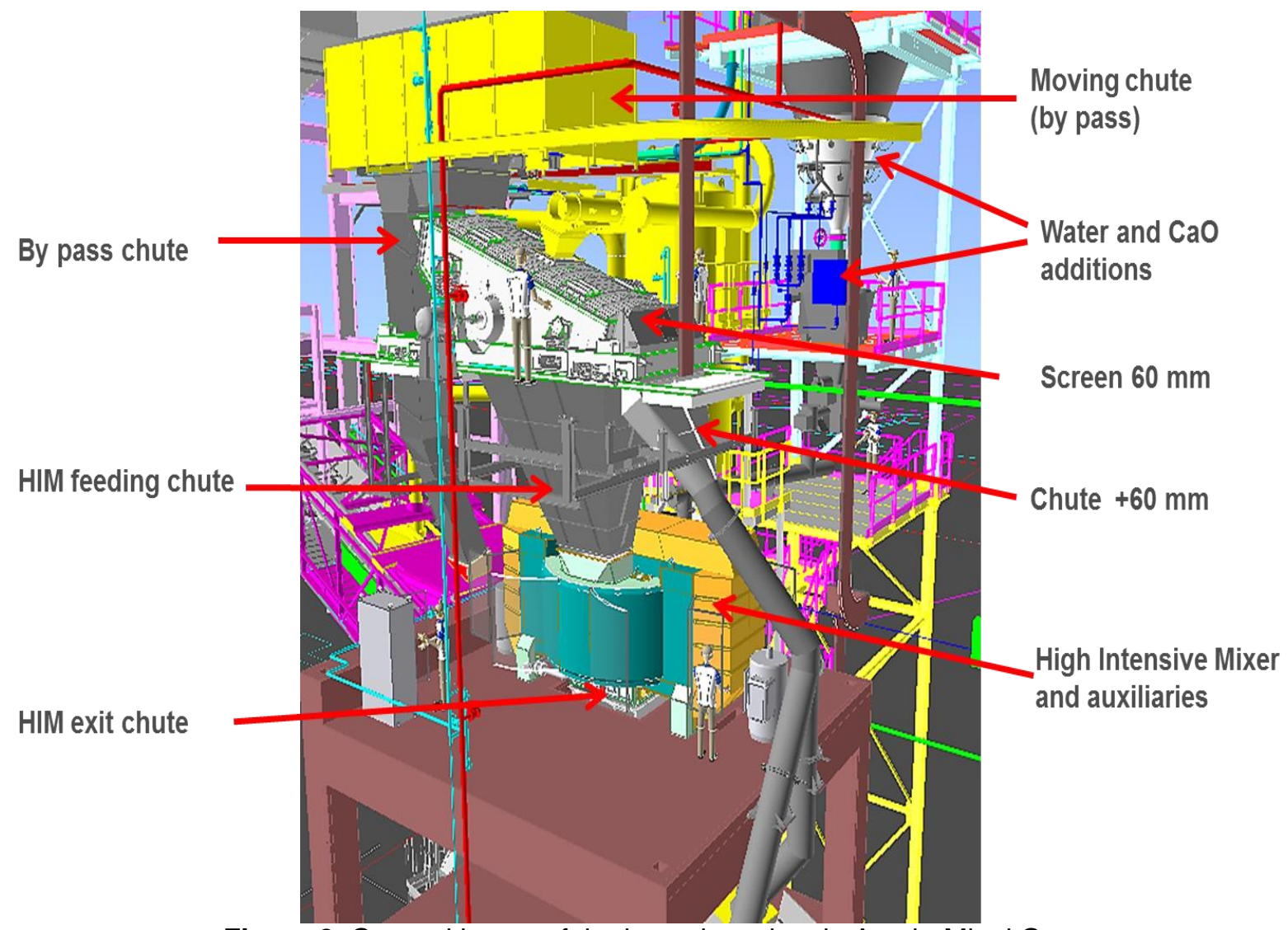

Figure 2. General layout of the intensive mixer in ArcelorMittal Gent

\subsection{Intensive Mixer}

In ArcelorMittal Gent, the intensive mixer (figure 3) was designed to mix the whole raw material flow with a nominal capacity of around $1000 \mathrm{t} / \mathrm{h}$. The main specifications of the machine are presented hereunder:

- One rotor of $0.8 \mathrm{~m}$ diameter, maximum rotation speed $180 \mathrm{RPM}$, frequency converter

- One rotor of $1 \mathrm{~m}$ of diameter, maximum rotation speed 143 RPM equiped with frequency converter.

- A pan of $3.3 \mathrm{~m}$ diameter and a total useful volume of $7.2 \mathrm{~m}^{3}$. The pan is equiped also with frequency converter, maximum rotation speed 8.9 RPM.

\footnotetext{
* Technical contribution to the $44^{\text {th }}$ Ironmaking and Raw Materials Seminar, $15^{\text {rd }}$ Brazilian Symposium on Iron Ore and $2^{\text {nd }}$ Brazilian Symposium on Agglomeration of Iron Ore, September $15^{\text {th }}$ to $18^{\text {th }}$, 2014, Belo Horizonte, MG, Brazil.
} 


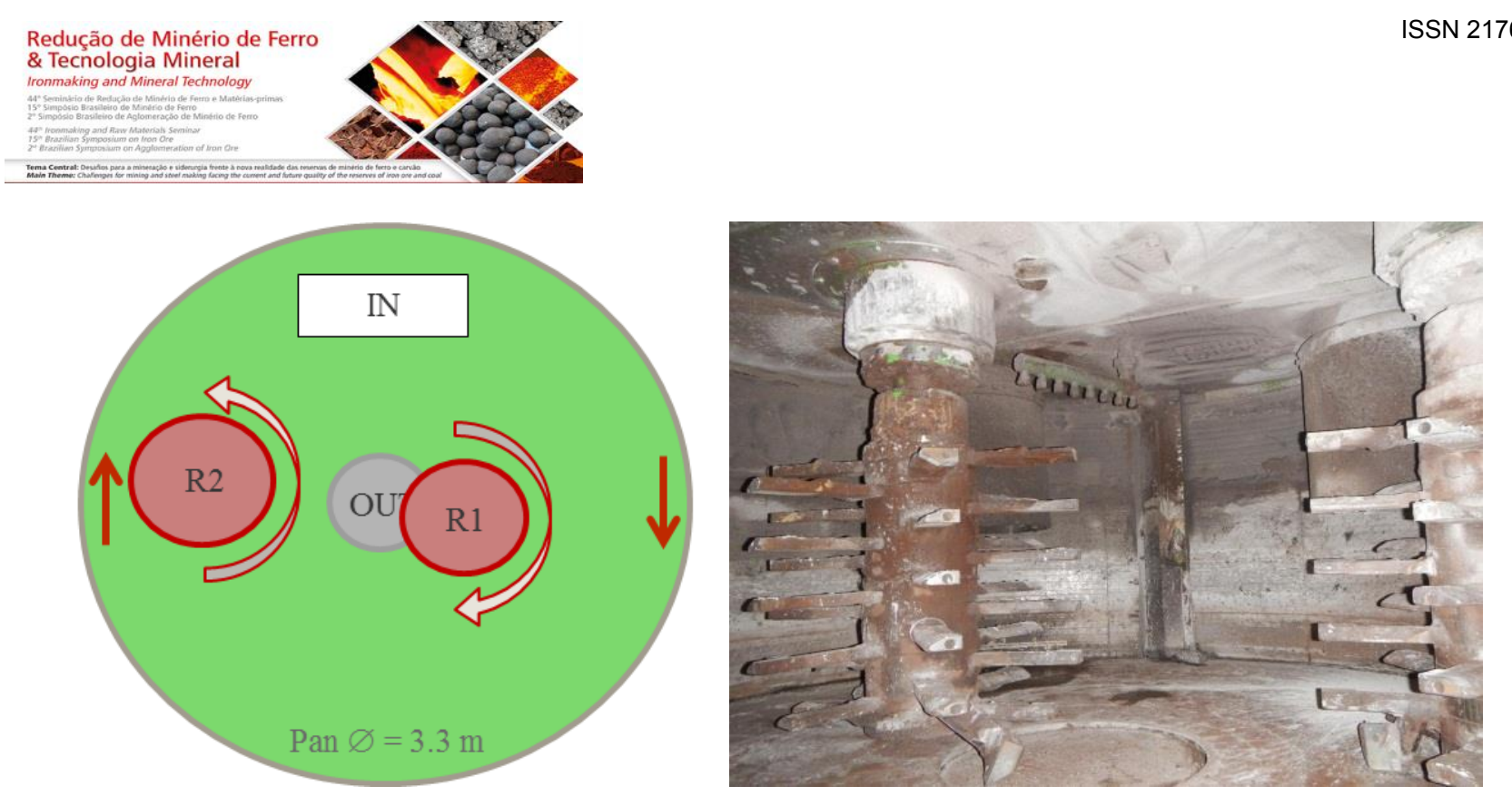

Figure 3. Top and inside view of the intensive mixer in ArcelorMittal Gent

\subsection{Industrial Trials Approach}

After integration of the intensive mixer in the sintering processing, series of test campaigns were organized with the following objectives:

- Optimizing the intensive mixer setting parameters based on granulation efficiency

- Optimizing drums operations

- Studying the impact of the intensive mixer regarding particle size distribution and sinter mix segregation at the sinter line charging point

- Evaluation of the intensive mixer's performances when operating with challenging process condition, integration of up to $40 \%$ of ultra-fine ores in the raw mix.

A large number of tests were performed whilst changing the mixer's setting points (rotors speed, pan speed, filling ratio), quicklime and water content/ratio as well as the ultra-fine ores level

\subsection{Cold Permeability Measurement}

The performance and control of the granulation efficiency are based on the measurement of the cold permeability by using a permeameter apparatus specially developed for the application. The samples were taken at the outlet of the intensive mixer, after the nodulizing drums and inside the pallet cars.

The principle is based on the measurement, at constant air flow rate, of the differential pressure across a certain volume of raw material granules located in a cell. The permeability in JPU (Japanese permeability unit) is then calculated by using the following formula:

$$
J P U=\frac{F}{A} *\left(\frac{H}{\Delta p}\right)^{0.6}
$$

F: Air flow meter in $\mathrm{m}^{3} / \mathrm{min}$

A: Cell area $\left(\mathrm{m}^{2}\right)$

$\mathrm{H}$ : Cell height $(\mathrm{mm})$

$\Delta \mathrm{p}$ : mean pressure drop $\left(\mathrm{mmH}_{2} \mathrm{O}\right)$

\footnotetext{
* Technical contribution to the 44 $4^{\text {th }}$ Ironmaking and Raw Materials Seminar, $15^{\text {rd }}$ Brazilian Symposium on Iron Ore and $2^{\text {nd }}$ Brazilian Symposium on Agglomeration of Iron Ore, September $15^{\text {th }}$ to $18^{\text {th }}$, 2014, Belo Horizonte, MG, Brazil.
} 
The figure below shows the measurement device:

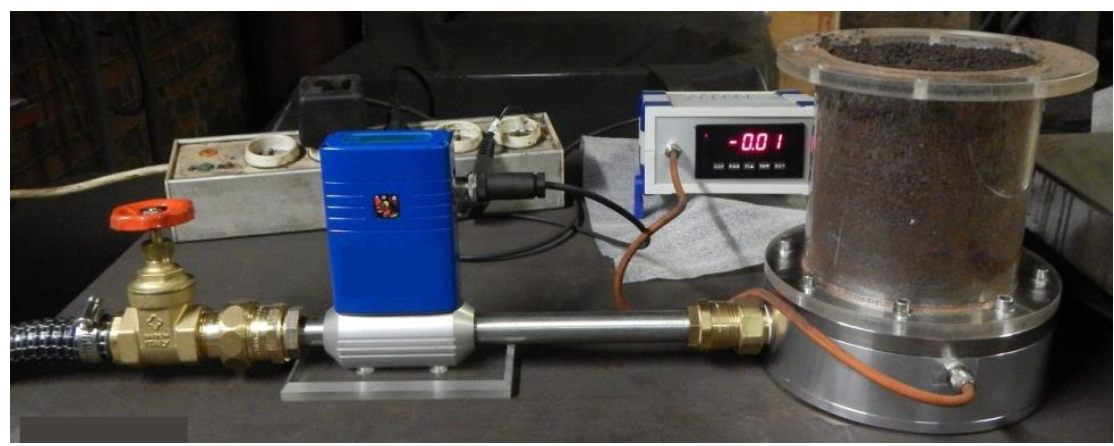

Figure 4. Permeameter

\section{RESULTS AND DISCUSSION}

\subsection{Impact of the Intensive Mixer on the Granulation Capacity}

\subsubsection{Intensive mixer setting parameter}

During the commissioning of the intensive mixer, different parameters such as filling rate, rotor speed, pan speed, water and lime content and addition were tested. Several test campaigns with different level of ultra-fine material were performed. In order to define the optimal process parameters and maximize the granulation efficiency, the permeability of the material in JPU was measured by the permeameter.

The better homogeneity and permeability of the raw mix, independently of the content of ultra-fines material, were obtained when operating with a maximum filling rate inside the intensive mixer $(>80 \%)$. The pan speed must also be at maximum speed whereas the speed of the rotor can be lower or intermediate. The addition of water must split according to a specific ratio between the intensive mixer and the drums. Thus, the water has to be mainly added in the intensive mixer. Regarding lime addition, better results are obtained by introducing $100 \%$ in the intensive mixer.

\subsubsection{Optimization of the rotating drums operation}

In order to get better granulation efficiency, some optimizations were done to the drums. The objective was to turn the mixing and pelletizing drums into complete pelletizing drums in order to get the best pelletisation performance.

After modification, an improvement of the granules growth of $+0.3 \mathrm{~mm}$ and the granules resistance at the line charging point were finally observed.

\subsubsection{Impact of the intensive mixer on granules}

A comparison between processes operated with intensive mixer and without intensive mixer revealed an improvement of the granulation capacity based on the pseudo-grain D50 [mm]. It has to be noted that raw material fluctuate over time. So, D50 should be recalculated taking into account these fluctuations in order to assess the real granulation capacity improvement. Thus, an improvement of $+0.55 \mathrm{~mm}$ of the pseudo-grain size D50 is observed (figure 5).

\footnotetext{
* Technical contribution to the 44 $4^{\text {th }}$ Ironmaking and Raw Materials Seminar, $15^{\text {rd }}$ Brazilian Symposium on Iron Ore and $2^{\text {nd }}$ Brazilian Symposium on Agglomeration of Iron Ore, September $15^{\text {th }}$ to $18^{\text {th }}$, 2014, Belo Horizonte, MG, Brazil.
} 


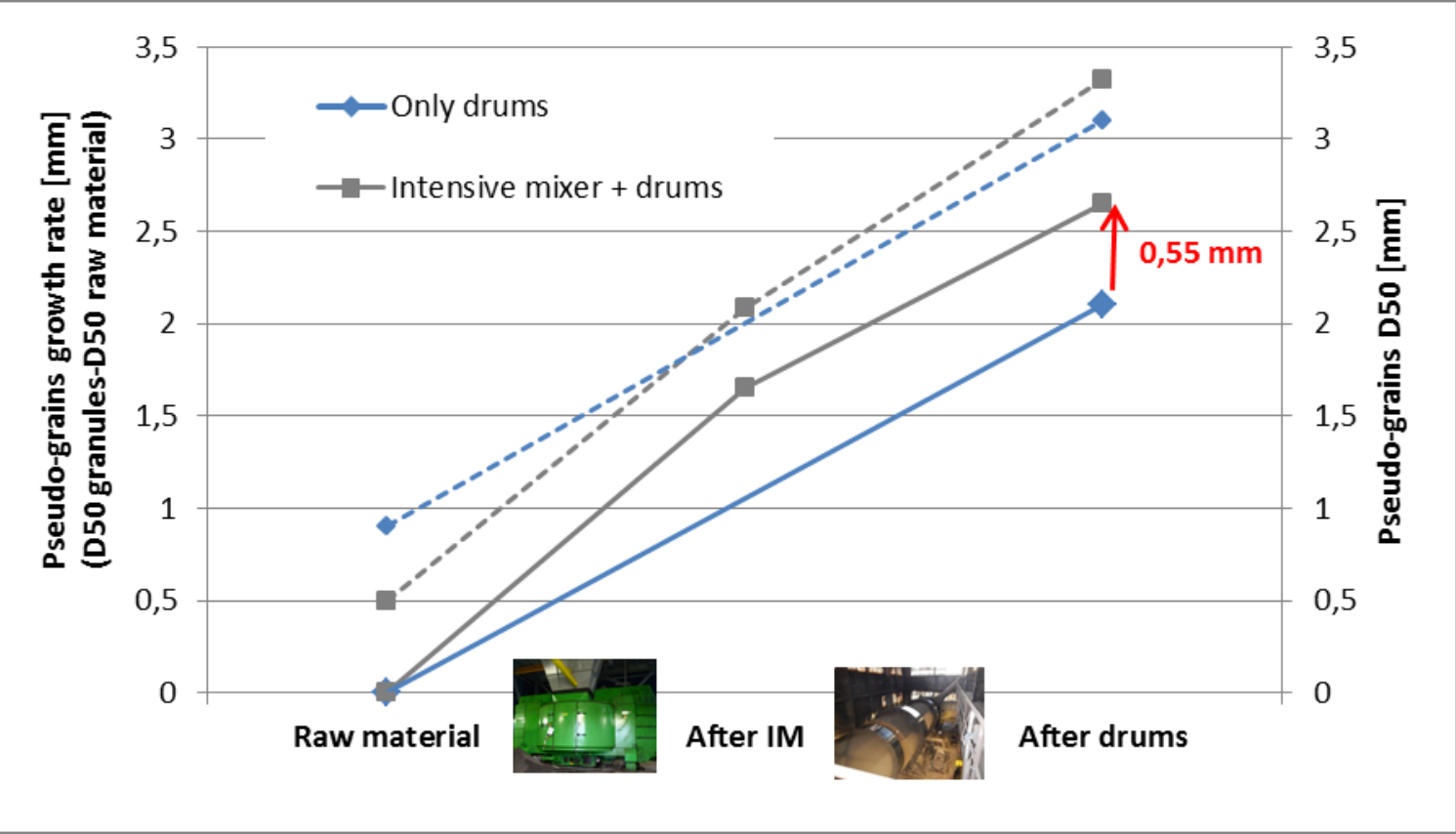

Figure 5. Improvement of the granulation capacity

In addition, with regard to wet granule and when the intensive mixer is in operation, it appears that there is:

- An increase of the cold permeability which can be correlated to the improvement of the wet granule size

- A reduction of the fraction $<1 \mathrm{~mm}$.

- An improvement of the granule resistance (figure 6) evaluated via the granulation index $([\%]<500 \mu \mathrm{m})$.

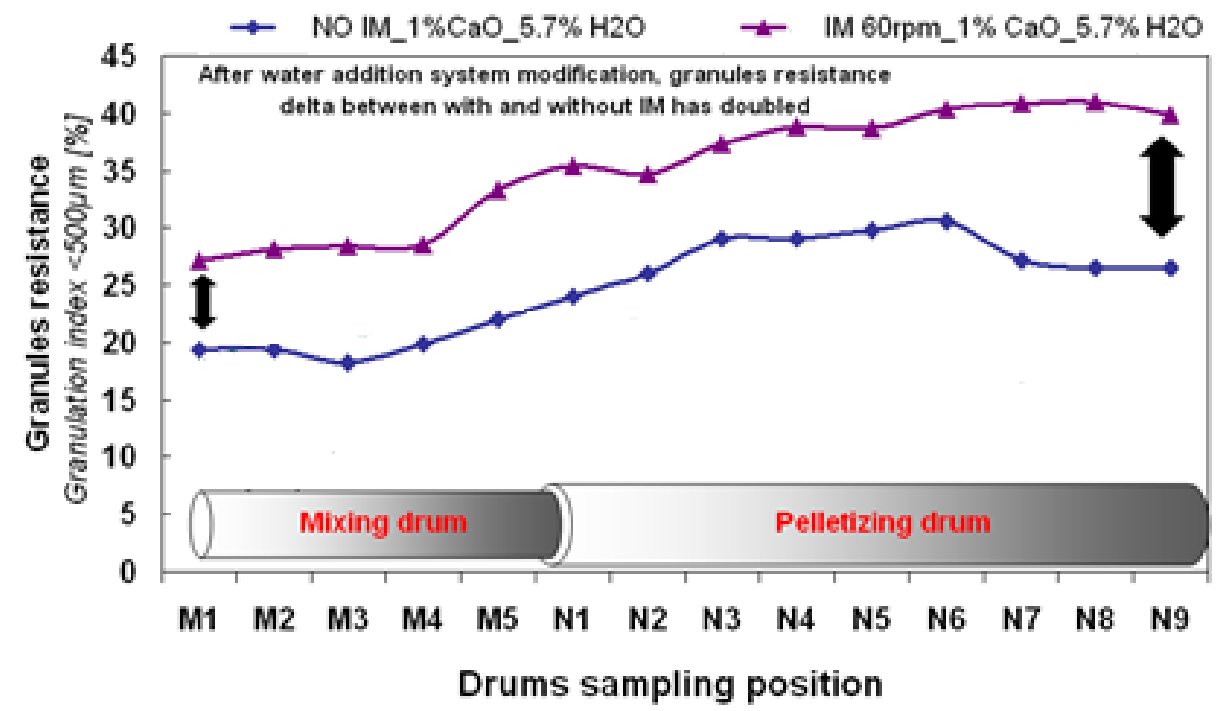

Figure 6. Evolution of the granule resistance across the drums with and without intensive mixer

* Technical contribution to the 44 $4^{\text {th }}$ Ironmaking and Raw Materials Seminar, $15^{\text {rd }}$ Brazilian Symposium on Iron Ore and $2^{\text {nd }}$ Brazilian Symposium on Agglomeration of Iron Ore, September $15^{\text {th }}$ to $18^{\text {th }}$, 2014, Belo Horizonte, MG, Brazil. 


\subsection{Impact of the Intensive Mixer on the Strand Charging}

The segregation was studied by using a metallic box (height $400 \mathrm{~mm}$ ), positioned on the hard sinter layer, just before the charging point. The box is then removed after the segregation plate, completely filled by the raw material. The box was divided in 5 identical layers which were physically and chemically analyzed.
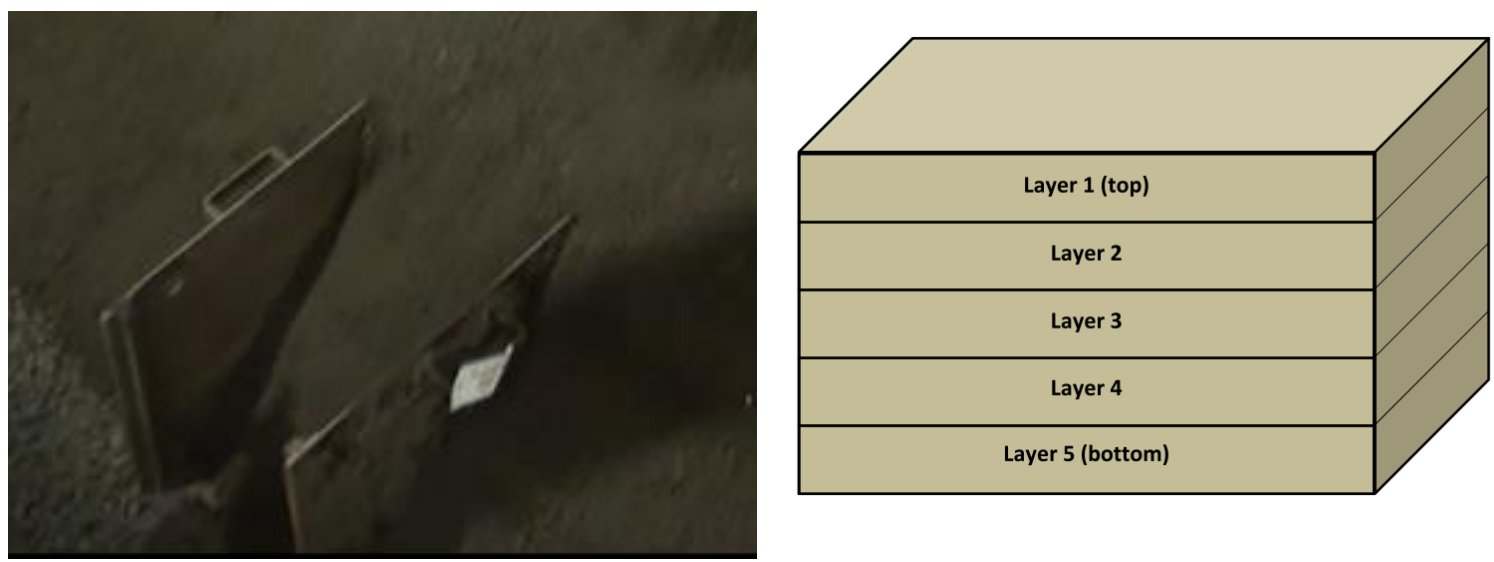

Figure 7. Principle of the segregation study

A comparison between process operated with intensive mixer and without intensive mixer was done by taking samples at the charging point and by analyzing the behaviors of wet granules over the sinter bed height.

It was observed that the intensive mixer, in comparison with the conventional drums system, impacted raw materials significantly by breaking isolated particles $(>3.15 \mathrm{~mm})$ and increasing the amount of fines particles, leading to an increase of $+5 \%$ to the fraction $<0.05 \mathrm{~mm}$. Nevertheless, this fraction is easily re-agglomerated. These phenomenon impacts blend segregation behavior (figure 8) by making:

- Blend D50 more homogeneous

- Fraction of material $<1 \mathrm{~mm}$ preferably on the top layer.

- Global particle size distribution more tight

- Iron and carbon analysis more homogeneous across the bed

- Better granules resistance evaluated via the Japanese granular index The figure below shows the behavior of the raw material whether the intensive mixer is in operation or not.

\footnotetext{
* Technical contribution to the 44 Ironmaking and Raw Materials Seminar, $15^{\text {td }}$ Brazilian Symposium on Iron Ore and $2^{\text {nd }}$ Brazilian Symposium on Agglomeration of Iron Ore, September $15^{\text {th }}$ to $18^{\text {th }}$, 2014, Belo Horizonte, MG, Brazil.
} 


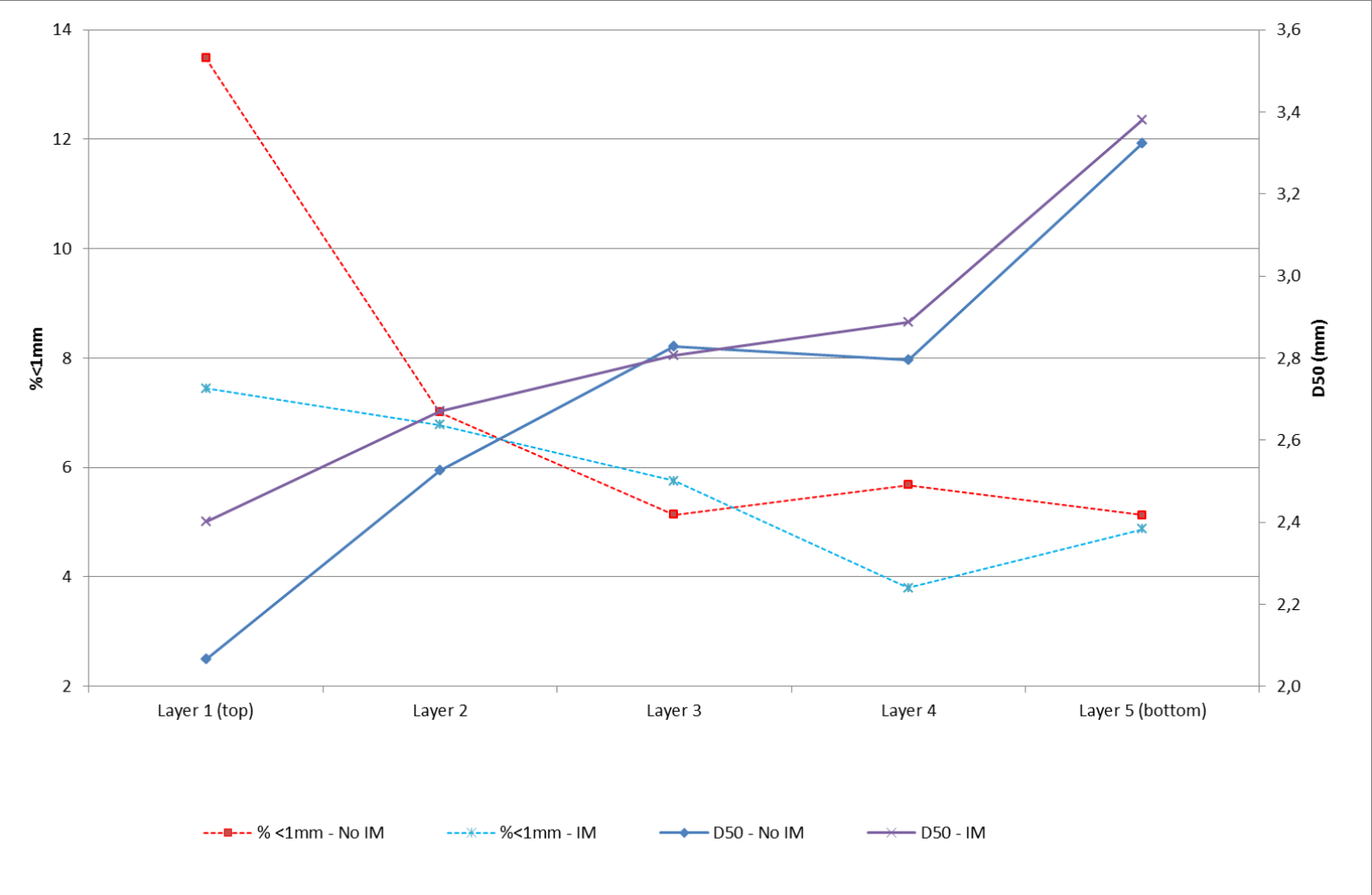

Figure 8. Segregation over the sinter machine.

It appears that the intensive mixer improves granules cohesive forces, avoids the release of fines particles through drying and maintains bed structure and permeability during sintering. One could affirm that due to high shear stress imposed to the particles by the rotor movement, fragile particles and granules are broken and can form stronger and denser pseudo-grains (supported by some trials with variation of rotors speed). Also, intense mixing imposed by these devices favors the contact between particles and granules, improving blend homogeneity and binders' efficiency.

\subsection{Impact of the Intensive Mixer In Challenging Condition on the Hot Performance}

Several industrial test campaigns, working with material flow of $900 \mathrm{t} / \mathrm{h}$, were done in order to compare the performance of the intensive mixer regarding hot sintering process and by increasing the ratio of ultra-fines material in the raw mix blend. The tests were conducted with challenging bedding composed of $40 \%$ fine ores. The value of water was optimized based on the measurement of cold permeability and the burnt lime level.

The effect of the intensive mixer was analyzed during stable process operation phases. Due to the fluctuation of the raw material over time, we have observed some variability in the process values. Nevertheless, by operating with intensive mixer, we have seen the following tendency:

- A slight improvement of the sinter strand productivity

- A decrease of the production of the sinter fines

- No negative impact on the sinter properties

- A minor impact on fuel consumption.

* Technical contribution to the $44^{\text {th }}$ Ironmaking and Raw Materials Seminar, $15^{\text {rd }}$ Brazilian Symposium on Iron Ore and $2^{\text {nd }}$ Brazilian Symposium on Agglomeration of Iron Ore, September $15^{\text {th }}$ to $18^{\text {th }}$, 2014, Belo Horizonte, MG, Brazil. 
It also appears that working with $1 \%$ of lime in a system drums gives a comparable productivity as working with $0.5 \%$ of lime in a system intensive mixer/drums. Conclusion also observed during the laboratory tests

\section{CONCLUSIONS}

Intensive mixers (vertical or horizontal, alone or followed by drums) allow to improve productivity and flexibility when increasing fine iron ores in the sinter feed. Nevertheless, an adjustment of water and binders' amount and position has to be carefully determined in order to get the best performance of the machine regarding raw material characteristic.

The main benefit brought by the intensive mixer concerns the granulation capacity enhancement in term of grains growth and resistance. The raw mix at the sinter line charging point is:

- Physically more homogenous, coarser and more resistant leading to an increase of the cold permeability of the material

- Chemically more homogeneous across the sinter bed height which affects the sinter belt machine charging and segregation phenomena.

\section{BIBLIOGRAPHY}

1 Voice EW et al. The permeability of sinter beds. Journal of the iron and steel institute. $2013: 136-139$

2 Lima MAFF et al. Improvement of sinter raw materials preparation by intensive mixer to cope with high level of fine iron ores. In: $1^{\text {st }}$ ESTAD \& 31 $1^{\text {th }} \mathrm{JSI} ; 2014$. p.172-173.

3 Van Loo F et al. Improved sinter preparation while using challenging material. In: $1^{\text {st }}$ ESTAD \& 31 th JSI; 2014. p.170-171.

4 Mascarenhas LP et al. Implementation of the intensive mixer at sinter plant. In: ICSTI, $6^{\text {th }}$ international congress on the science and technology of ironmaking; 2012; Rio de Janeiro, Brasil. São Paulo: ABM; 2012. p.777-787.

* Technical contribution to the 44 $4^{\text {th }}$ Ironmaking and Raw Materials Seminar, $15^{\text {rd }}$ Brazilian Symposium on Iron Ore and $2^{\text {nd }}$ Brazilian Symposium on Agglomeration of Iron Ore, September $15^{\text {th }}$ to $18^{\text {th }}$, 2014, Belo Horizonte, MG, Brazil. 